\title{
BMJ Global Health It's time to address sexual violence in academic global health
}

\author{
Valery Ridde, ${ }^{\oplus}$ Christian Dagenais, ${ }^{2}$ Isabelle Daigneault ${ }^{2}$
}

To cite: Ridde V, Dagenais C, Daigneault I. It's time to address sexual violence in academic global health. BMJ Glob Health 2019;4:e001616. doi:10.1136/ bmjgh-2019-001616

Handling editor Seye Abimbola

Received 4 April 2019 Accepted 6 April 2019

Check for updates

C Author(s) (or their employer(s)) 2019. Re-use permitted under CC BY-NC. No commercial re-use. See rights and permissions. Published by BMJ.

${ }^{1} \mathrm{IRD}$ (French Institute For Research on sustainable Development), CEPED (IRDUniversité de Paris), Universités de Paris, ERL INSERM SAGESUD Paris, France

${ }^{2}$ Department of Psychology, Université de Montréal, Montréal, Québec, Canada

Correspondence to Professor Valery Ridde; valery.ridde@ird.fr

\section{INTRODUCTION}

Looking back over the first year of the global \#MeToo movement that brought sexual violence (from harassment to coercion and assault) out in the open, ${ }^{1}$ we note that this issue has received little attention in academic global health. Recent cases of sexual misconduct in Joint United Nations Programme on HIV and AIDS (UNAIDS) ${ }^{2}$ and Oxfam show that the global health community must act to address this problem. ${ }^{3}$ In just a few months, the \#MeToo movement raised awareness, stimulated new debates and placed this issue squarely on the public agenda in politics, business and entertainment. But academic global health still does not adequately prepare (women and men) students and academics for this problem; and recent discussions on global health training ignore the problem. ${ }^{4}$ Indeed, there is an urgent need to implement evidence-based comprehensive and integrated prevention strategies to address sexual violence in global health academic research. ${ }^{5}$

Collaboration between partners from countries with unequal incomes and power is common in academic global health. ${ }^{67}$ While challenges of power, money, publication, data use, and so on, within such collaborations are widely discussed, ${ }^{6-10}$ there is relative silence around sexual violence. Gender inequality in global health is increasingly discussed $^{11}$-as scientific panels are often composed of a majority of (or only) men and the work of unpaid young women represents a large proportion of global health internships. ${ }^{12}$ There is a new movement to highlight women leaders in global health, ${ }^{13}$ and junior women researchers are calling to depatriarchalise science for French-speaking women. ${ }^{14}$ Despite these discussions, the general lack of consideration for sexuality issues in research fieldwork remains. ${ }^{1516}$ In 1985, Gurney stated, "for female fieldworkers, reciprocity... may be problematic if powerful males in the setting expect sexual favors in return for research access." 11 There may also be a culture of sexual harassment in global health due to expectations that the level of openness and comfort with sexuality (required to work in some aspects of the field) translates into an openness towards sexual advances ${ }^{17}$ - even apparently innocuous sexualizations have a considerable effect on the way gender and sexuality are negotiated during the research encounter. 18

There are many guides to support researchers engaged in global health partnerships to ensure that collaborations are fair and ethical, ${ }^{1920}$ but none addresses sexual violence head on. While data on the content of each course are not available, the same lacunae seem to apply to preparation for global health internships. ${ }^{21-23} \mathrm{~A}$ recent systematic review of US medical students' global health internships found no mention of sexual harassment or assault in curricula. ${ }^{24}$ Likewise, existing academia-wide movements do not include specific consideration for the peculiarities of global health-for example, the Athena Swan Charter for the advancement of gender equality in higher education ${ }^{25}$ and the Title IX US civil rights law which has enabled students to compel colleges and universities to take action against gender-based sexual harassment and assault on campuses. ${ }^{26}$

\section{HOW ARE WE INVOLVED AS ACADEMICS? OUR (RE)AWARENESS OF THE PROBLEM}

Stories of sexual harassment of female students by academics (and of sexual relations between academics and students) are not new. But they are all too rarely addressed in academic training, especially in the Global North where universities are increasingly developing global health training programmes and sending more and more students into the field. Compared with domestic students in North America, international students are at higher risk of experiencing sexual violence on campus ${ }^{2728}$ and are less likely to seek help if assaulted. ${ }^{28}$ Academic institutions need to be held accountable for the well-being of the 
foreign students they host and the domestic students they send abroad.

In recent months, three young women shared with one of us, in informal discussions, their experiences of sexual harassment in the field. One of them met with many actors involved in her subject in the country concerned. She reported that one researcher she was advised to meet was very insistent, on several occasions. And he was not the only one. After a few days of fieldwork and too many insistent requests, she bought and wore a fake wedding ring, pretending to be a married woman to avoid harassment. In 1977, Carol Warren reported using the same strategy in the USA, ${ }^{29}$ which suggests that this problem is not confined to a particular social context and that this coping strategy is quite common. The other two young women were in direct contact with high-ranking individuals in government and an international financial institution to conduct interviews to obtain data for their research. The insistent demands of these high-ranking individuals for more informal, off-duty and very personal meetings put these two students in a very uncomfortable position, at risk to their integrity and research.

As with sexual violence in universities in the Global North, ${ }^{30-32}$ victims of harassment and assault abroad are often unable or reluctant to disclose and may wait until the end of their fieldwork, or even graduation, to disclose. They may only disclose to informal sources of support, such as friends and family. In all three cases presented above, even though there had never been any cause for suspicion, the supervisor was indirectly responsible for putting students in contact with colleagues who used their power for sexual harassment. This situation-that is, supervisors themselves being the indirect cause of the event-may further delay disclosure to formal/academic sources of support and limit our ability to act preventively in future placements.

These deeply unsettling cases led us to rethink our role and responsibilities as academics. Of course, we could avoid the issue by arguing to ourselves that the cases are on the boundary between sexual harassment and seduction; that 'sexuality enacted in the field can be experienced as both threatening and pleasant. ${ }^{18}$ The boundary can sometimes be blurred. Some have described how 'to be a young, female graduate student definitely has advantages in a male-dominated setting. ${ }^{11}$ And some academics have claimed that female students harass them to get good grades. However, these cases are likely the exception. But perhaps less of an exception are male students from universities in the Global North who, during global health research field placements, engage in inappropriate and sometimes predatory sexual behaviour.

The consequences of sexual harassment on women's academic careers, health and well-being are now well known, including declines in productivity, higher stress and less funding. ${ }^{33}$ In a recent survey of 198 global health organisations, including just one university, only 25 had a sexual harassment policy that meets the four best practices according to Global Health 50/50: commitment and definition; confidentiality and non-retaliation; staff training; and reporting and accountability. ${ }^{3}$ As with other inequalities in global health research partnerships, sexual violence will likely continue 'for as long as the culture of consciously unknowing what is known continues unchallenged. ${ }^{, 8}$ We are at the heart of a 'public secret', a concept well known in public health. ${ }^{34}$

\section{WHAT CAN ACADEMICS AND ACADEMIC INSTITUTIONS D0?}

Our actions must be informed by up-to-date prevention guidelines on sexual violence on college/university campuses. But these need to be adapted to address specific issues in academic global health, with programmes for all students and academics (male and female) to address both victimisation and perpetration, and for entire academic communities so that active bystanders can contribute to changing cultural norms and behaviours among peers. ${ }^{5}$ Such approaches should include: (1) raising awareness; (2) acknowledging barriers to change; and (3) increasing action through skills practice. But until such a prevention package is adapted and implemented, what can academics and academic institutions do? We propose the following:

1. Immediately sanction perpetrators according to policy guidelines. Although it is difficult for universities to sanction international research partners who are not under their jurisdiction, one sanction for violating the policy would be to cease collaboration.

2. Adopt a comprehensive sexual harassment and violence policy globally, spearheaded by schools of global (public) health in the Global North. Accreditations given by the Council on Education for Public Health in North America and the Association of Schools of Public Health in the European Region should add the presence of these policies as an evaluation criterion. These policies should be shared with universities and funding agencies, who are in a good position to raise researchers' awareness about sexual violence and require adherence to sexual violence prevention policies in funded research. They should clearly state what constitutes sexual violence, including harassment. They should also refer to a code of conduct between faculty/researchers/supervisors and students, guidelines for reporting and a clear set of sanctions for violating the policies. Global South partners should be made aware of the policies, agree to adhere to them for continued partnership and be held responsible for the conduct of their employees and collaborators. The policies must be systematically included in the guides to good practice for scientific partnerships in global health and be disseminated to all academics, for example, through a massive open online course.

3. Stop participating in the culture of sexual harassment. This means intervening with our harassing colleagues when we are made aware of such situations, rather than solely advising young women on how to 'manage' them (eg, 'wear a wedding ring', 
'don't meet him alone', and so on). Upstream, academics should be more aware of the situation by serving as mentors and by systematically discussing the issue during classes and before students leave for the field. ${ }^{35}{ }^{36}$ Academics referring students to their colleagues should have a responsibility to act when made aware of sexual violence on their part by following policy procedures and enforcing sanctions. Academics also must be trained in how to receive disclosures and to support students who have been harassed or assaulted. Such training should be survivor centric, increase policy and service awareness and reduce victim blaming. This, in turn, would increase confidence in institutional responses and encourage disclosures. Confident listening spaces should exist, both before and during fieldwork, to discuss and suggest possible solutions. The scientific literature on challenges facing young women doing research in a male-dominated field should be mobilised for training purposes. ${ }^{16} 18293738$ It is also important to make available in the field mentors trained in harassment management to support anyone (women and men) involved in these situations and help them find appropriate solutions, or at least talk about them.

4. Fund and implement sexual harassment and assault resistance training for students as part of an integrated sexual violence prevention strategy based on the best available evidence. ${ }^{5}$ Evidence-based programmes exist to help students become more active bystanders ${ }^{39}$ and better resist sexual violence, ${ }^{4041}$ as well as programmes that show promise for reducing male students' perpetration of sexual violence. ${ }^{42}$ If 'the female researcher cannot prepare for all eventualities, ... at least she can enter the setting with some idea of how she might respond to sexist remarks, sexist behavior, and sexual hustling. ${ }^{11}$ For example, the Enhanced Assess, Acknowledge, Act programme has resulted in an annual victimisation reduction of up to $63 \%$ in five forms of sexual violence experienced by female students in Canada. ${ }^{40}$ A working group should be set up to determine whether this programme can be specifically adapted for global health research, tested and evaluated.

\section{CONCLUSION}

The eminent anthropologist Françoise Héritier, who died a month after \#MeToo began, envisaged that 'the consequences of this movement [could] be enormous. On condition that we lift not just one corner but the entire veil, pull all the threads to rethink the question of the relationship between the sexes, tackle this status of male domination and destroy the idea of an irrepressible male desire. ${ }^{43}$ One year later, nothing has changed in academic global health. The National Academies of Sciences, Engineering, and Medicine in the USA has just proposed important structural changes to protect against sexual harassment. ${ }^{33}$ When will academic institutions involved in global health take up the charge? Maybe it's time for global health to have its own \#MeToo movement.
Acknowledgements We thank the persons who entrusted us with and allowed us to share their stories for constructive purposes and the persons who agreed to read a previous version of this text to improve its arguments. Thanks also to Donna Riley for the editing support and Seye Abimbola for the editorial support.

Contributors VR had the idea about the paper and wrote the first draft. CD and ID improved the paper. All authors have read and approved the final text.

Funding The authors have not declared a specific grant for this research from any funding agency in the public, commercial or not-for-profit sectors.

Competing interests None declared.

Patient consent for publication Not required.

Ethics approval Not requiered

Provenance and peer review Not commissioned; internally peer reviewed.

Data availability statement № additional data are available.

Open access This is an open access article distributed in accordance with the Creative Commons Attribution Non Commercial (CC BY-NC 4.0) license, which permits others to distribute, remix, adapt, build upon this work non-commercially, and license their derivative works on different terms, provided the original work is properly cited, appropriate credit is given, any changes made indicated, and the use is non-commercial. See: http://creativecommons.org/licenses/by-nc/4.0/

\section{REFERENCES}

1. Basile KC, Smith SG, Breiding MJ, et al. Sexual violence surveillance: Uniform definitions and recommended data elements, version 2.0. Atlanta, Georgia, 2014.

2. UNAIDS Independent Expert Panel. Report on the work of the independent expert panel on prevention of and response to harassment, including sexual harassment; bullying and abuse of power at UNAIDS Secretariat. Geneva: UNAIDS Programme Coordinating Board, 2018.

3. Global Health 50/50. The global health 50/50 report 2019: equality works. London: University College London Centre for Gender and Global Health, 2019.

4. Oni T, Yudkin JS, Fonn S, et al. Global public health starts at home: upstream approaches to global health training. Lancet Glob Health 2019;7:e301-2.

5. Orchowski LM, Edwards KM, Hollander JA, et al. Integrating Sexual Assault Resistance, Bystander, and Men's Social Norms Strategies to Prevent Sexual Violence on College Campuses: A Call to Action. Trauma Violence Abuse 2018;1524838018789153.

6. Ridde V, Capelle F. La Recherche en santé mondiale et les défis des partenariats Nord-Sud. Rev Can Santé Publique 2011;102:152-6.

7. Koplan JP, Bond TC, Merson MH, et al. Towards a common definition of global health. The Lancet 2009;373:1993-5.

8. Gautier L, Sieleunou I, Kalolo A. Deconstructing the notion of "global health research partnerships" across Northern and African contexts. BMC Med Ethics 2018;19.

9. Smith E, Hunt M, Master Z. Authorship ethics in global health research partnerships between researchers from low or middle income countries and high income countries. BMC Med Ethics $2014 ; 15$.

10. Ouattara F, Ridde V. Expériences connues, vécues ... mais rarement écrites. À propos des relations de partenariat Nord-Sud, 231-246. Nouv Prat Soc 2013;25:231-46.

11. Gurney JN. Not one of the guys: the female researcher in a maledominated setting. Qual Sociol 1985;8:42-62.

12. McBride B, Mitra S, Kondo V, et al. Unpaid labour, \#MeToo, and young women in global health. The Lancet 2018;391:2192-3.

13. Clark J, Zuccala E, Horton R. Women in science, medicine, and global health: call for papers. The Lancet 2017;390:2423-4.

14. Ouedraogo S, Gautier L, Mac-Seing M, et al. De-patriarchalizing and levelling science for French-speaking women in low and middleincome countries. The Lancet 2019.

15. Harries B. What's sex got to do with it? when a woman asks questions. Womens Stud Int Forum 2016;59:48-57.

16. Jackson R, Kelly M. Women Researching in Africa: The Impact of Gender. Cham: Springer International Publishing, 2019.

17. Herbenick D, van Anders SM, Brotto LA, et al. Sexual harassment in the field of sexuality research. Arch Sex Behav 2019;48:997-1006.

18. Kaspar H, Landolt S. Flirting in the field: shifting positionalities and power relations in innocuous sexualisations of research encounters. Gender, Place \& Culture 2016;23:107-19. 
19. Larkan F, Uduma O, Lawal SA, et al. Developing a framework for successful research partnerships in global health. Glob Health $2016 ; 12$.

20. Canadian Coalition for Global Health Research. Building Respectful and collaborative partnerships for global health research learning resource. Ottawa: Canadian Coalition for Global Health Research no date, 2019.

21. Drain PK, Mock C, Toole D, et al. The emergence of undergraduate Majors in global health: systematic review of programs and recommendations for future directions. Am J Trop Med Hyg 2017;96:16-23.

22. Crump JA. Ethical considerations for short-term experiences by trainees in global health. JAMA 2008;300.

23. Elit L, Hunt M, Redwood-Campbell L, et al. Ethical issues encountered by medical students during international health electives: ethical issues in international health electives. Med Educ 2011;45:704-11.

24. PM L, Park EE, Rabin TL, et al. Impact of global health electives on us medical residents: a systematic review. Ann Glob Health 2018;84.

25. Rosser SV, Barnard S, Carnes M, et al. Athena Swan and advance: effectiveness and lessons learned. The Lancet 2019;393:604-8.

26. Department of Justice. Overview of title IX of the education amendments of 1972, 2015. Available: https://www.justice.gov/crt/ overview-title-ix-education-amendments-1972-20-usc-1681-et-seq

27. Bergeron M, Hébert M, Ricci S, et al. Violences sexuelles en milieu universitaire au Québec : Rapport de recherche de l'enquête ESSIMU. Montréal: Université du Québec Montréal, 2016.

28. Bonistall PostelEJ. Violence against international students: a critical gap in the literature. Trauma Violence \& Abuse 2017;1524838017742385

29. Warren CAB, Rasmussen PK. Sex and gender in field research. Urban Life 1977:6:349-69.

30. Sabina C, Ho LY. Campus and college victim responses to sexual assault and dating violence. Trauma, Violence, \& Abuse 2014;15:201-26.

31. DeLoveh HLM. Where Do I Turn? A Qualitative Investigation of College Students' Helpseeking Decisions After Sexual Assault
Victimization, 2014. Available: https://search.proquest.com/docview/ 1556433113?accountid=12543

32. Nogrady B. Sexual harassment rife in Australian science, suggests first workplace survey. Nature 2019;567:14-15.

33. Fairchild AL, Holyfield LJ, Byington CL. National academies of Sciences, engineering, and Medicine report on sexual harassment: making the case for fundamental institutional change. JAMA 2018;320.

34. Geissler PW. Public secrets in public health: knowing not to know while making scientific knowledge. Am Ethnol 2013;40:13-34.

35. Cole DC, Johnson N, Mejia R, et al. Mentoring health researchers globally: diverse experiences, programmes, challenges and responses. Global Public Health 2016;11:1093-108.

36. Hamelin A-M, Paradis G. Population health intervention research training: the value of public health internships and mentorship. Public Health Rev 2018;39.

37. De Craene V. Fucking geographers! Or the epistemological consequences of neglecting the lusty researcher's body. Gend Place Cult 2017;24:449-64.

38. Johnstone L. Landscapes of Desire: The Effect of Gender, Sexualized Identity, and Flirting on Data Production in Rwanda and Zimbabwe. In: Johnstone L, ed. The politics of conducting research in Africa. Cham: Springer International Publishing, 2019: 75-95.

39. Moynihan MM, Banyard VL, Cares AC, et al. Encouraging responses in sexual and relationship violence prevention: what program effects remain 1 year later? J Interpers Violence 2015;30:110-32.

40. Senn CY, Eliasziw M, Barata PC, et al. Efficacy of a sexual assault resistance program for university women. $N$ Engl J Med 2015;372:2326-35.

41. Senn CY, Eliasziw M, Hobden KL, et al. Secondary and 2-year outcomes of a sexual assault resistance program for university women. Psychol Women Q 2017;0361684317690119.

42. Gidycz CA, Orchowski LM, Berkowitz AD. Preventing sexual aggression among college men: an evaluation of a social norms and bystander Intervention Program. Violence Women 2011;17:720-42.

43. Cojean A. Françoise Héritier : Il faut anéantir l'idée d'un désir masculin irrépressible. Le Monde, 2017. 